\title{
Regional Spatial Approach to Differences in Rural Economic Development: Insights from Serbia
}

\author{
Žana Jurjević (1), Stanislav Zekić, Danilo Đokić (1) and Bojan Matkovski *(i) \\ Department of Agricultural Economics and Agribusiness, Faculty of Economics in Subotica, \\ University of Novi Sad, 24000 Subotica, Serbia; zana.jurjevic@ef.uns.ac.rs (Ž.J.); \\ stanislav.zekic@ef.uns.ac.rs (S.Z.); danilo.djokic@ef.uns.ac.rs (D.Đ.) \\ * Correspondence: bojan.matkovski@ef.uns.ac.rs; Tel.: +381-24628049
}

Citation: Jurjević, Ž.; Zekić, S.; Đokić, D.; Matkovski, B. Regional Spatial Approach to Differences in Rural Economic Development: Insights from Serbia. Land 2021, 10, 1211. https://doi.org/10.3390/ land10111211

Academic Editors: Krystyna Kurowska and Cezary Kowalczyk

Received: 30 September 2021 Accepted: 5 November 2021 Published: 8 November 2021

Publisher's Note: MDPI stays neutral with regard to jurisdictional claims in published maps and institutional affiliations.

Copyright: (c) 2021 by the authors. Licensee MDPI, Basel, Switzerland. This article is an open access article distributed under the terms and conditions of the Creative Commons Attribution (CC BY) license (https:// creativecommons.org/licenses/by/ $4.0 /)$.

\begin{abstract}
Rural regions with a larger share of the primary sector in the overall economy are limited in their ability to achieve a sufficient level of competitiveness. In countries such as Serbia, where rural areas play an important role, addressing the problems affecting these areas is important for overall development. The purpose of this study is to determine the socioeconomic performance of the rural regions of Serbia and the EU in order to indicate the position of Serbia's rural areas in the process of European integration. NUTS 3 (NUTS 2 for Germany) was used for analysis, and from this an Index of Socioeconomic Performance was created. This Index was created using Factor Analysis. The results point to Serbia lagging behind other EU regions in terms of development, with most of Serbia's rural regions receiving the lowest ratings. These results are cause for alarm and indicate a need to create strategies that will direct resources towards key issues in these areas, whose potential would be adequately used through the implementation of rural policy measures, with the aim of overall socioeconomic development.
\end{abstract}

Keywords: rural; factor analysis; underdeveloped regions; European integration; Serbia

\section{Introduction}

Depending on the methodology applied, rural areas comprise about $80 \%$ of land in Serbia, and contain between $40 \%$ and $50 \%$ of the population, which indicates the specific relevance of these areas for the overall Serbian economy. The development of local infrastructure and basic services in rural areas, including leisure and culture services, the renewal of villages and activities aimed at the restoration and upgrading of the cultural and natural heritage of villages is an essential element for the socioeconomic development of rural areas [1]. Rural regions are mainly based on sectors that use natural resources such as agriculture, forestry, fishing, oil, gas, and electricity. Therefore, competitiveness of the primary sector remains the policy focus for developing these areas. In more developed countries, tourism and services, or renewable energy production are associated sectors that also rely on natural resources and make significant contributions to the socioeconomic development of rural areas. The strength of the link between agriculture and other sectors is influenced by various factors such as the natural characteristics of the terrain (land quality, climate, and local tourist attractions), infrastructure, the overall strength of the national economy, the educational level and entrepreneurial potential among the local population, and access to public finances [2]. Namely, in rural areas with demographic problems, rural tourism could be an additional activity that could make the traditional agricultural function of those places secondary, so it could change those areas into multifunctional spaces [3]. Rural areas are usually poorer and less populated than urban areas. Berc et al. [4] indicate that in rural areas poor availability of certain social services is often accompanied by weak coordination of service providers within the social welfare system, which speaks in favour of the present difficulties in the implementation of deinstitutionalization and decentralization of social services. 
The income disparities between rural and urban areas in Serbia have deepened with the process of transforming a centrally planned economy into a market-oriented economy. Following a dynamic transition process, a clear strategic goal for Serbia is integration into the European Union (EU), which requires additional economic and institutional changes. The dynamics of European integration differ among the formerly communist and socialist countries. For Serbia, which is currently a candidate country for EU membership, the experience in pre-accession negotiations of New Member States (NMS), i.e., Central and Eastern Europe (CEE) are a valuable benchmark for future integration processes. Böwer and Turrini [5] investigated the effects of EU accession on NMS, and they concluded that this region has widely benefited from economic and institutional integration with the EU. The socioeconomic growth recorded in NMS after the recovery from transition shock in the early 1990s has been impressive.

The study presented in this paper focuses on Serbia's rural areas, as well as future development strategies for these areas, in order to better prepare them for EU integration. The agricultural sector has a significant position in the overall Serbian economy and even more so in the rural areas, where it is often the dominant activity for most of the population [6]. Based on agri-environmental conditions, the rural areas of Serbia can be divided into two regions: northern and southern. The northern region has exceptional agri-environmental conditions for agricultural development and a high concentration of food industry [7]. The southern part of Serbia is characterized by mountainous areas with relatively poorer conditions for agricultural production. In addition, both regions are characterized by an unfavourable demographic structure with a very low level of education of the rural population. According to Petrović et al. [8], modest knowledge and the absence of supplementary skills in the rural population are limitations for the total capacity and competitiveness of the labour force in rural areas, which can be anticipated as one of the burdening factors in the economic development of these areas.

Creating an appropriate rural policy in Serbia within the conditions of current European integration requires harmonization with the EU's Common Agricultural Policy (CAP), which is one of Serbia's future priorities. The CAP represents the benchmark for future policy, so pressures of the EU accession negotiations, as well as EU pre-accession support will be the key elements in the process of adapting policies to the CAP [9]. However, harmonization of legislation, institutional capacity building, and policy reform in agriculture and rural development are complex issues. Therefore, economic, social, political, and environmental conditions must be taken into account when defining political measures and instruments. Namely, as space and land are limited resources, an era of rapid urbanization should be effectively controlled in line with sustainable development principles [10]. The principles of sustainable development integrate political, economic, and social measures in order to meet the needs of communities without compromising the ability of future generations to meet their needs [11].

The European Union offers various opportunities for receiving financial support, which allows the exchange of best practices whereby the benefit is realized by Serbia, and even certain regions that have adequate cooperation with EU countries, such as Vojvodina [12]. The European Commission [13] estimated that good progress was made by adopting the action plan for acquis alignment in agriculture and rural development and implementing the Instrument for Pre-accession Assistance for Rural Development program (IPARD II). Although it is very important to access these funds, primarily because of the relative significance of agriculture for the overall economy as well as Serbia's rural areas, it must also be emphasized that pre-accession assistance does not solve the key development problems of rural areas, which require a comprehensive, long-term, territorial-based national policy that respects local specificities and the needs of the rural population [14]. Sustainable development of agriculture entails sustained economic growth, technological advancement, efficient resource management, and an increase in quality of life in rural areas [15]. 
In order to monitor and compare the socioeconomic conditions of different heterogeneous territories across EU countries, the Nomenclature of Statistical Territorial Units (NUTS) was adopted by the EU. The NUTS classification is a framework for determining standardized statistics of all EU Member States at three basic levels: NUTS 1 (population of 3 to 7 million), NUTS 2 (population of 800,000 to 3 million) and NUTS 3 (population of 150,000 to 800,000 ) [16]. The Nomenclature of Statistical Territorial Units has also been defined for EU candidate countries (Serbia, North Macedonia, Albania, Montenegro, and Turkey), which allows for comparison of regions or districts across Europe. In Serbia, this classification is the basis used to draft documents needed to implement projects that should be financed by the European Union's structural funds [17].

The study presented here is designed to help candidates for membership determine the position of their regions vis-à-vis EU regions and as such can be applied to other candidate countries in addition to Serbia: Montenegro, Albania, North Macedonia, and Turkey. Moreover, this study will be a step forward in comparison with the existing literature, given the minimal amount of research conducted at the regional level in Serbia. The results provide an empirical basis for creating future rural development strategies for Serbia by giving a detailed insight into socioeconomic performance at the regional level, and enabling a comparative analysis with EU countries as well as with regions within Serbia itself. The methodology adopted in this way, and when applied to other candidate countries, would provide an overview of socioeconomic performance across Europe. Identifying a candidate country's level of development in relation to the Member States is important for the harmonization of policies, such as Serbia's rural policy and the EU CAP or regional policies. This indicates the practical contribution this study can provide. The purpose of this study is to determine the socioeconomic performance of rural regions of Serbia and the EU in order to indicate the position of Serbia's rural areas in the process of European integration. More specifically, the aim is to detail the socioeconomic performance of rural regions, which will be evaluated with an Index of Socioeconomic Performance evaluated by Factor Analysis (FA).

Based on the purpose of this paper, the main hypothesis of the research is created:

- The socioeconomic performance of Serbian rural regions corresponds to the socioeconomic performance of rural regions of NMS.

\section{Theoretical Background}

Regional development plays a significant role in the EU. The regional aspect has been given more importance in the EU, primarily through the Cohesion policy, i.e., strengthening the economic, social, and territorial cohesion within the EU. One of the EU's key objectives is to reduce development inequalities between developed and economically underdeveloped regions. EU enlargement to the south, and especially to the east, has been followed by growing inequalities within the Union. The more developed, pre-2004 member states (EU-15) channelled financial resources through the Cohesion policy to less developed NMS to support transformation and economic convergence [18]. The EU Cohesion policy does not include only economic convergence, but it is certainly still the most important objective of this policy due to large income discrepancies. In recognizing a need to assess more place-sensitive policies, highlighting heterogeneity generally contributes to the debate on the future of the post-2020 Cohesion Policy, by providing effective comparative tools to support new policy instruments [19]. In addition to this policy, others, namely the EU rural development policy, have had significant impacts on the regional development of the EU as a whole [20].

The EU Cohesion policy plays an important role in supporting the socioeconomic development of rural areas and, together with the European Agricultural Fund for Rural Development (EAFRD), involves directing financial resources towards the reconstructing and revitalizing these areas. EAFRD is part of the EU's CAP, but with a regional focus [21]. Matthews [22] states that one of the general objectives of the CAP for rural development in the upcoming period (2021-2027) is to "strengthen socio-economic performance in 
rural areas" through specific objectives such as attracting and retaining young farmers in rural areas; promoting employment, social inclusion and local development through increased bioenergy production and sustainable forestry; an adequate response to the increased demand for health-safe foods; and the use of innovation and digitalization for both agriculture and rural areas. Increased demand for renewable energy can be a good development opportunity for rural areas. Vukadinović and Ješić [23] point out that creating "green jobs" through the concept of a circular economy is important for employment growth, given that economic growth is becoming an effective use of resources and renewable energy resources, as well as the use of comparative advantages of the natural environment. However, the heterogeneity of rural areas or regions significantly impedes the convergence process. The objectives of rural policy have become multidimensional and focus on increasing the wellbeing of rural residents. Generally speaking, quality of life has several dimensions: (1) an economic dimension, in which the income of the population depends on being able to find employment in companies that are productive and competitive; (2) the social dimension, which refers to accessibility to services; and (3) a local dimension, which refers to the environment [2]. Although it is necessary examine rural areas according to several aspects, the socioeconomic aspect is always an important link to future development. The European development model is characterized by balancing economic and social performance, and quality of life, as a top European priority [24]. In most of the rural typologies, the structure of employment by sectors was analysed in order to define the role and significance of agriculture and other sectors within the rural area. Moreover, the importance of the sector is determined by their share in the Gross Value Added (GVA) of the region. The employment structure is also important for the region's socioeconomic development. The traditional approach to identifying regional competitiveness is based on an analysis of GDP per capita [25]. Michalek and Zarnekow [26] pointed to the use of GDP per capita (calculated at NUTS-2 or NUTS-3 level) as: (a) a standard measure of a regional level of welfare; (b) a basic criterion of eligibility criteria for EU funding under structural funds, and (c) the main quantitative indicator of the effectiveness of the policies being pursued. Moreover, Prus et al. [27] have used a significantly larger number of variables to determine the socioeconomic characteristics of certain regions.

Domazet et al. [28] indicate the importance of following up macrocompetitiveness of the EU, or countries around the world by the European Commission in its European Competitiveness Report, which examines the basic performance of the competitiveness of the EU as a whole, member states, or certain economic activities, while the WEF (World Economic Forum) affirmed the GCI Index (Global Competitiveness Index) for following up basic indicators of the competitiveness of countries around the world. Regional competitiveness is the ability of a region to offer an environment attractive and sustainable for businesses and in which residents can live and work [29]. As noted, each round of EU enlargement deepened regional differences. Here, the focus will be on the EU enlargement of 2004, since expansion from that period on included countries with the same historical legacy of centrally planned economies as Serbia (with the exception of two island countries, Cyprus and Malta). The countries of Central Europe, and Eastern Europe in particular, are considered to be less economically developed regions in comparison to the original EU member states (for example Benelux, Germany, and France) due to the strategy of socialism, i.e., industrialization which led to economic, social, and environmental decline. Accordingly, to better facilitate accession for the CEE countries, two EU programs were launched at the end of the 1990s, which strongly shaped the regional policies of the CEE countries: the Instrument for Structural Policies for Pre-Accession (ISPA) and the Special Accession Program for Agriculture and Rural Development (SAPARD), in order to prepare future members for Cohesion Policy (first fund) and for the EU CAP (second fund) [30]. Bachtler and Ferry [31] point to the importance of using these funds when CEE countries join the EU, as well as to different strategies in spending structural funds in these countries, which have further affected regional inequalities. 
Rural development largely depends not only on national policies (rural, regional, social, etc.) but also on factors that influence heterogeneity, with future development based on addressing specific problems affecting a particular territory [32]. The development of regions, or the convergence of less developed, usually rural regions with developed regions, creates a need to territorialize and regionalize development policies, while also seeking competitive advantages for localities [33]. Resolving the issue of rural development necessitates an integrated approach that requires cross-sectoral cooperation at all levels (national, regional, and local). Issues related to rural policy in Serbia are reflected not only in the low level of funds allocated for rural development but also in the defined measures, which are directed more towards investing in agricultural production itself rather than in the development of infrastructure in rural areas, the environment, or improving quality of life in rural areas [34]. Limited human resources, lack of regulatory framework and funding, and insufficient experience in both policy formulation and major project management are the main obstacles to effective rural development policies in Serbia, the most important task of which should be strengthening local self-government capacity [35]. In the EU, the LEADER (an acronym for the French Liaison Entre Actions de Développement de l'Economie Rurale) program supports capacity-building of local authorities and the development of local partnerships, and emphasizes the importance of rural development projects launched at the local level to revitalize rural localities [36]. The involvement of Local Action Groups (LAGs) in the decision-making and priority-setting process for local territorial development, i.e., a bottomup approach, is a significant segment of EU rural development policy. However, the process of regionalization and decentralization in Serbia is insufficient; the distribution of responsibilities is asymmetric at different territorial levels, which will be unsustainable in the future. Although today we are in the Fourth Industrial Revolution with significant social transformation in parallel with technological change [37], rural areas lag significantly behind urban areas, with limited access to technology, information, and new knowledge.

\section{Materials and Methods}

In this research, the methods of multivariate statistical analysis were used, i.e., Factor Analysis, which aims to reduce large numbers of variables to a more manageable number while discarding a minimum amount of useful information. The advantage of FA is that it enables researchers to take an important step towards deeper understanding of a complex and multidimensional territory such as, in this case, rural areas [38]. Moreover, the advantage of using factorial techniques is that no prejudgment of the results is required, as the technique itself determines the importance of individual factors (dimensions) within any solution derived from it [39]. The conditions required for the FA to be applied were checked by Bartlett's test and by Kaiser-Meyer-Olkin (KMO) sampling adequacy testing [40]. The $\mathrm{KMO}$ value is a measure of adequacy of the correlation matrix to perform the FA. The KMO test ranges from 0.0 to 1.0, but values should be greater than 0.5 .

Factor loadings represent the correlation between the original variables and the factors and are key to understanding the nature of a particular factor. When using practical significance as the criteria, Hair et al. [40] suggested that factor loadings in range \pm 0.50 or greater are considered practically significant. Interpretation of factors, based on factor loadings, is an important step. If it is necessary, factor rotation should be performed. The goal of VARIMAX rotation is to maximize the variance of factor loadings by making high loadings higher and low ones lower for each factor [41]. After factor extraction, it is necessary to calculate the factor scores for each unit of observation for each factor. Factor scores are standardized to have a mean of 0 and a standard deviation of 1 . Factor score calculations enable creation of an index for each factor so that observation units can be ranked. There are also some limitations and disadvantages of the method used in this analysis. For example, Cloke and Edwards [42] admit that multivariate classification techniques in general are subject to considerable methodological disagreement and that 
the validity of individual classifications rest on their usefulness far more than on their methodological basis.

More systematically, this research will follow certain statistical assumptions and procedures when conducting FA:

- A defined research problem indicates the use of research FA;

- R type factor analysis;

- Data standardization by Z-transformation;

- Bartlett's test and the Kaiser-Meyer-Olkin test (KMO) (>0.6);

- Correlation matrix (at least 0.3 or higher Pearson correlation coefficient);

- Analysis of the Principal Components as a method of factor extraction;

- Kaiser's criterion to determine the number of factors (eigenvalue greater than 1);

- VARIMAX factor rotation with Kaiser normalization;

- Accepted factor loads in the range greater than \pm 0.50 , and

- Calculated factor scores for all observation units, for all factors.

In this analysis, NUTS 3 were selected as the observation units for both the EU countries (with the exception of Germany, for which NUTS 2 were used) and Serbia. Despite criticism, for example, Hedlund [43] pointed to need for typologies based on high-resolution data, beyond the urban-rural continuum, respectively the administrative boundary, this level was chosen for two reasons. First, it represented the lowest administrative and territorial level at which data could be found for all countries included in the analysis; second, regional typologies applied at this level aimed to analyse and monitor rural and urban development by implementing certain regional and rural policies and programs. NUTS 3 allowed a detailed representation of EU rural space [44]. It is worth noting that the degree of differentiation among European rural regions is in line with the transitional processes described in the literature [45], which is especially significant for former socialist states, both in the EU and in those, such as Serbia, which are candidates for membership. Spatial (i.e., territorial) distribution of regional performance was considered: different components followed different territorial paths across Europe, suggesting the existence of a puzzled core-periphery pattern, where within-region differences also matter [46].

Since this study focuses on rural regions, predominantly urban regions were excluded as defined by Tercet (Regulation (EU) 2017/2391) [47], i.e., the EU's Urban-rural typology, because they have urban centres with over 500,000 inhabitants, and they contain at least $25 \%$ of these regions' populations. Instead, the focus was primarily on predominantly rural and intermediate regions. These two groups of areas were defined as "non-urban" areas [48]. Certain limitations to this approach should also be noted. Primarily, intermediate regions were of particular concern, since they have a wide range of different spatial characteristics. However, the inclusion of intermediate regions in the analysis was justified by the need to consider as large a geographical area as possible, as well as by the need to include most of Serbia in the analysis, which, according to the Urban-rural classification of the $\mathrm{EU}$, was designated as a state with one predominantly urban region (Belgrade District), five predominantly rural regions, and 19 intermediate regions. A total of 691 units were included in the analysis, of which 667 were at NUTS 3 and 24 at NUTS 2. Certain areas, although classified as intermediate or predominantly rural, were excluded from the analysis due to lack of data (primarily for the newly created NUTS 3 areas), or due being located geographically outside of the European continent.

The Eurostat database [49-51] was used for this study, and the time period was a seven-year average from 2012 to 2018, with some exceptions for France and Poland (threeyear average from 2014 to 2016). The analysed period also coincided with the period of candidacy for Serbia's EU membership (from 2012 to the most recent data available). The observation units in this paper were all EU countries and Serbia. The Statistical Package for the Social Sciences program-SPSS Statistics 20.0 was used for the purposes of this paper. Variables used to create the regional Index of Socioeconomic Performances, using FA, were: share of employees in the primary sector in the total number of employees (\%) (EMPL_PRIMARY); gross domestic product (GDP) per capita (purchasing power 
standard-PPS) (GDP_PER_CAPITA); primary sector share in total gross value added (GVA) (\%) (GVA_PRIMARY); total labour productivity (total GVA of all activities per employee) (EUR/person) (LABOUR_TOTAL); and labour productivity in the primary sector (GVA of the primary sector per employee in the primary sector) (EUR/person) (LABOUR_PRIMARY). The selection of variables was determined by the availability of data in the database used. Bearing in mind that Serbia is a candidate country for EU membership, the choice of data in the Eurostat database is scarce. Additionally, according to previous research, the selected variables well describe the socioeconomic performance of rural areas, which is the main subject of this analysis.

\section{Results}

This study began with the selection of variables with an emphasis on the vital sector of rural areas. The results of the KMO test as a measure of sample adequacy (0.730) were moderately good according to the Kaiser classification. In addition, Bartlett's test of sphericity was statistically significant (Table 1). The results of these two tests indicated the adequacy of the use of Factor Analysis in this study. Subsequently, a Correlation Analysis was performed, followed by a Factor Analysis.

Table 1. KMO and Bartlett's Test.

\begin{tabular}{lcc}
\hline \multicolumn{2}{c}{ Kaiser-Meyer-Olkin Measure of Sampling Adequacy } & 0.730 \\
& Approx. Chi-Square & 2720.081 \\
Bartlett's Test of Sphericity & df & 10 \\
& Sig. & 0.000 \\
\hline
\end{tabular}

Source: the authors' calculations.

This factor explained $71.511 \%$ of total variance, with eigenvalues higher than 1 (3.576) (Table 2). The correlation matrix indicated that GDP per capita was positively correlated with labour productivity (total economy and primary sector), while it was negatively correlated with the share of employees in the primary sector as well as the share of the primary sector in total GVA (Table 2), thus indicating that high dependence on the primary sector is a feature of regions that are in a less favourable economic situation and are thus less competitive regions. Factor loadings for this dimension are also presented in Table 2. The positive sign in front of the factor loadings of the variables GDP per capita, total labour productivity of all sectors, and labour productivity in the primary sector indicate overall socioeconomic development in the region, while the negative sign in front of the factor loadings of the variables share of employees in the primary sector as well as the share of the primary sector in the creation of GVA indicate that the primary sector is of less importance in more economically developed regions. The dominant variable within this factor, and with the highest correlation with the factor, was the GDP per capita (0.872). The calculated factor scores for this factor indicated the level of economic development, or wellbeing, across regions in the EU and Serbia, with the best rated observation units showing the best socioeconomic performance.

Factor scores, i.e., Index of Socioeconomic Performance, were ranked within a range of -3 to 3 and divided into quintiles. The averages for the five groups identified in Table 3 were drawn according to the level of socioeconomic development. Group 1, which included most of the intermediate and predominantly rural regions in Serbia, had an average of $27.6 \%$ of employees working in the primary sector; the primary sector had an $11.2 \%$ share of GVA creation, and the lowest levels of GDP per capita, and labour productivity both in total and in the primary sector. These results are disturbing and point to the great importance of the primary sector in the overall regional economies of NUTS 3 regions. The share of the primary sector in employment and GVA of the region declines and GDP per capita and labour productivity increases were highest in Group 1 and then decline for each subsequent group. In Group 5, the average share of employment in the primary sector was 3\% and the average share of GVA was $2 \%$, which indicates other sectors contribute much more to the economy. There has been a decline in the share of employees in agriculture in the EU-15 since 1990, with 
an average reduction of 2-3\% per year, which has resulted in an absolute reduction in the agricultural workforce by about 340,000 workers, or 190,000 annual work units (AWU) [52]. According to the same source, the only exceptions in the EU-15 that do not show a declining trend in the agricultural workforce are in those regions with a high proportion of part-time workers and a larger share of farms engaged in other profitable activities.

Table 2. Results of Factor Analysis: Socioeconomic performance of intermediate and predominantly rural regions.

\begin{tabular}{|c|c|c|c|c|c|}
\hline \multicolumn{6}{|c|}{ Correlation Matrix } \\
\hline & Empl_primary & GDP per capita & GVA_primary & Labour_total & Labour_primary \\
\hline Empl_primary & 1.000 & -0.635 & 0.742 & -0.675 & -0.603 \\
\hline GDP_per_capita & -0.635 & 1.000 & -6.14 & 0.847 & 0.611 \\
\hline GVA_primary & 0.742 & -0.614 & 1.000 & -0.593 & -0.316 \\
\hline Labour_total & -0.675 & 0.847 & -0.593 & 1.000 & 0.764 \\
\hline Labour_primary & -0.603 & 0.611 & -0.316 & 0.764 & 1.000 \\
\hline \multicolumn{6}{|l|}{ Sig. (1-tailed) } \\
\hline Empl_primary & & 0.000 & 0.000 & 0.000 & 0.000 \\
\hline GDP_per_capita & 0.000 & & 0.000 & 0.000 & 0.000 \\
\hline GVA_primary & 0.000 & 0.000 & & 0.000 & 0.000 \\
\hline Labour_total & 0.000 & 0.000 & 0.000 & & 0.000 \\
\hline Labour_primary & 0.000 & 0.000 & 0.000 & 0.000 & \\
\hline \multicolumn{6}{|l|}{ Variance Explained } \\
\hline & \multicolumn{5}{|c|}{ Eigenvalues } \\
\hline Component & Total & \multirow{2}{*}{\multicolumn{2}{|c|}{$\begin{array}{c}\text { \% of Variance } \\
71.511\end{array}$}} & \multirow{2}{*}{\multicolumn{2}{|c|}{$\begin{array}{c}\text { Cumulative \% } \\
71.511\end{array}$}} \\
\hline 1 & 3.576 & & & & \\
\hline \multicolumn{6}{|l|}{ Factor Analysis } \\
\hline & \multicolumn{5}{|c|}{ Factor loadings } \\
\hline Empl_primary & \multicolumn{5}{|c|}{-0.819} \\
\hline GDP per capita & \multicolumn{5}{|c|}{0.872} \\
\hline GVA_primary & \multicolumn{5}{|c|}{-0.788} \\
\hline Labour_total & \multicolumn{5}{|c|}{0.861} \\
\hline Labour_primary & \multicolumn{5}{|c|}{0.692} \\
\hline
\end{tabular}

Factor extraction method: Principal Components Analysis. Source: the authors' calculations.

Table 3. Group average.

\begin{tabular}{cccccc}
\hline & Empl_Primary & GDP_Per_Capita & GVA_Primary & Labour_Total & Labour_Primary \\
\hline Group 1 & 27.58795 & $11,086.29227$ & 11.24873 & $15,408.37$ & 8126.198 \\
Group 2 & 12.93303 & $16,639.61631$ & 5.829002 & $29,293.47$ & $16,186.62$ \\
Group 3 & 7.685439 & $20,311.40772$ & 3.884153 & $46,029.36$ & $27,705.58$ \\
Group 4 & 4.879643 & $25,531.23977$ & 2.953308 & $59,381.36$ & $37,400.79$ \\
Group 5 & 2.954538 & $31,519.9294$ & 2.030506 & $66,572.24$ & $45,255.65$ \\
\hline
\end{tabular}

Source: the authors' calculations.

In Figure 1, the darkest colour indicates the group with the best socioeconomic performance, and the group with the lowest socioeconomic performance is marked with the lightest colour. Regional inequalities are noticeable both among different countries and within one country. In this study, the focus was on several significant regional inequalities within the observation units. 


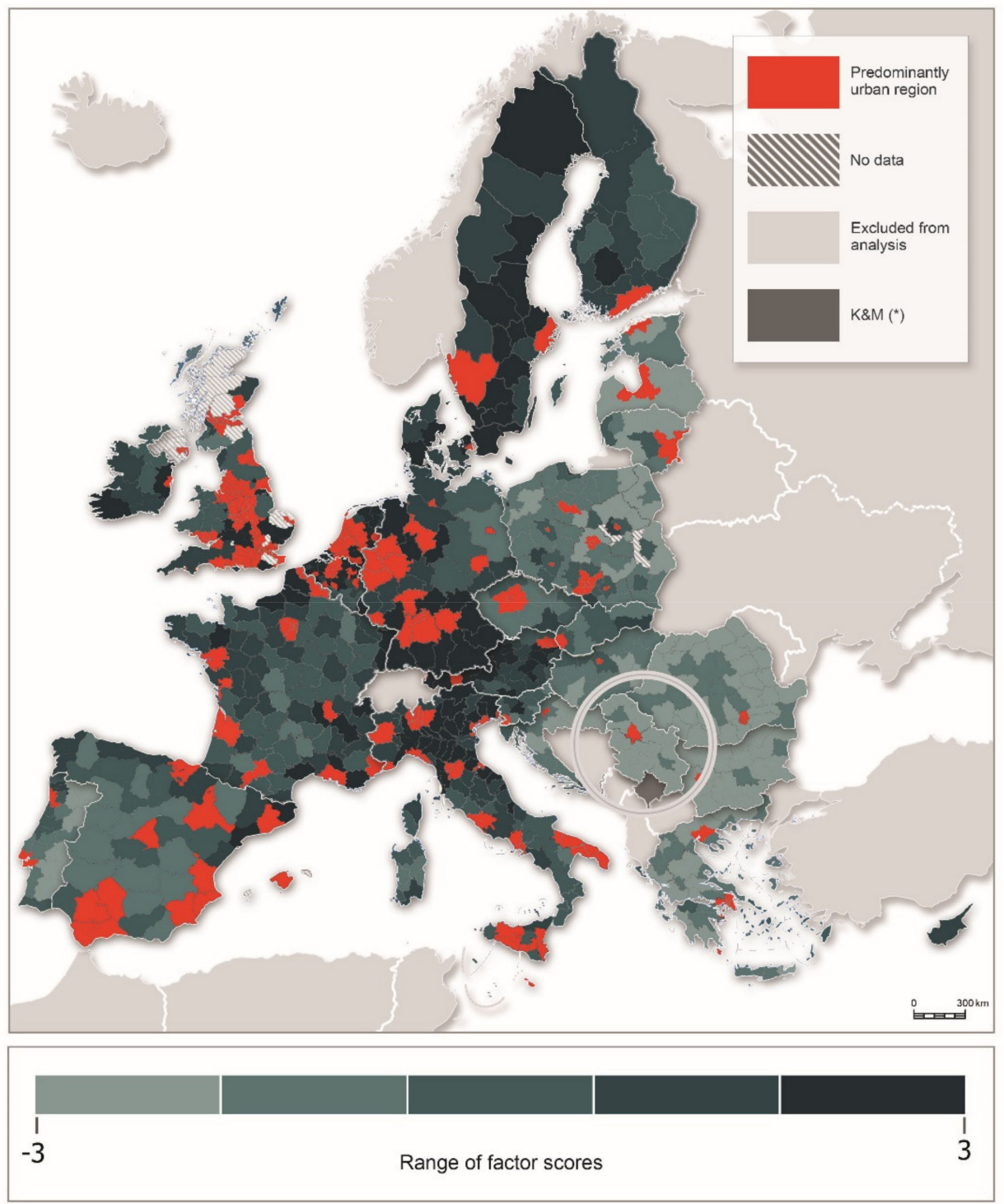

Figure 1. Index of Socioeconomic Performance of regions in EU plus Serbia as candidate for membership. Source: Author processed based on results of FA. Note: The specific status of Kosovo and Metohija excluded it from the analysis. Adobe Photoshop CC 2015 and NUTS 3 maps of the European Commission were used.

\section{Discussion}

From the country-level perspective, most EU countries have regions with different socioeconomic performance and range from Group 1 to Group 5 (such as Italy). Two exceptions are the Netherlands and Sweden, whose regions are mostly classified as part of Group 5 and in some cases Group 4. However, in countries such as Serbia, Romania, Bulgaria, Croatia, Latvia, and Estonia, all regions are classified as Groups 1 and 2 (the lowest socio-economic performance). These countries are characterized by the centralized development of the regions around their capital cities (usually the only predominantly urban region). The large gap between capital regions and other regions within one country indicates significant pressure on the capital region to pull development from other regions, often leaving resources in other regions untapped. Such regional inequalities within countries' borders are defined in relation to the capital city-other regions.

Some countries have clear north-south and east-west divisions. In Italy, for example, most regions in the north fall into Group 5, and on Figure 1 they are marked with the darkest colour. This part of Italy is an industrial and service centre, whereas southern 
Italy is not. Germany is another example of this east-west division, and is one where inequality between east and west has been an important issue in regional policy since the fall of the Berlin Wall. Unemployment is more prevalent in the east and young and educated people most often most often migrate west. A declining birth rate in the area of the former East Germany and restructuring of the economy has further deepened these divisions [53]. In some countries, regional development mismatches are present as a consequence of historical circumstances, as noted by Biczkowski et al. [54] in the example of Poland. Additionally, according to Adamowicz [55], the Polish regions in the east are less developed and have poorer socioeconomic performances. Gorzelak [30] argues that regional differences in CEE countries draw on legacies from the earlier period and that, within most newly formed countries, there are significant regional differences in which the eastern parts are less economically developed than those in the west of the countries. This is attributed to the proximity of western regions to the highly developed EU-15 countries, and that the positive economic effects have "spilled over" into the western regions of these newer members. According to Figure 1, this appears to be the case in Poland as well as in the regions of the former Socialist Federal Republic of Yugoslavia (SFRY), which now belong to the separate countries of Slovenia, Croatia, and Serbia (the other former SFRY countries, Northern Macedonia, Bosnia and Herzegovina and Montenegro, were not included in the analysis). Specifically, the best socioeconomic performance was identified in the intermediate and predominantly rural regions of Slovenia. This could be due to the fact that the Slovene private sector has historically been one of the largest recipients in Central and Eastern Europe of financing from highly developed countries [56].

There was also a clear difference in the level of socioeconomic performance between the EU-15, and especially in the area encompassing Northern Italy, Austria and Germany, part of France, the Benelux, the United Kingdom, and the NMS. This is the current state of historical patterns of urbanization in the EU and it comprises Europe's metropolitan core. This pattern was observed as far back as 1989, when a group of French geographers, led by Roger Brunet, defined an area of Europe, later referred to as the "Blue Banana", that was highly urbanized and industrialized, and which connected regions from Manchester and London in the United Kingdom to Lombardy in Italy, passing through the Benelux countries, France, and the western part of Germany and Austria [29].

Of course, these regional differences between the EU-15 and NMS do not apply to all CEE regions (e.g., Czech Republic, Slovakia, Slovenia, and Poland). Mostly the regions near the capitals are able to offer better conditions for the development of other branches of the economy (tourism, trade, the financial sector, etc.). As is illustrated in Figure 1, the eastern part of the EU from the Baltic countries, eastern Poland, Slovakia, Hungary, Romania, Serbia (candidate country), Croatia to Greece, is characterized by areas with the lowest socioeconomic performance, i.e., a high share of the primary sector in employment and GVA, low GDP per capita, and insufficient productivity levels for the entire economy and the primary sector. In some former socialist states, the situation is better, for example in western parts of Poland, the Czech Republic, and Slovakia, while the regions of Romania, Bulgaria, and Serbia are the majority in Group 1, which have the lowest socioeconomic performance, and the highest share of the economy is in the primary sector. According to a European Commission report, some former socialist states have completed the process of agricultural reconstruction through the transfer of labour from agriculture to other sectors (Czech Republic and Slovakia), while in some NMS such as Romania and Bulgaria, during the transition, the share of employment in agriculture increased due to government investment in agricultural enterprises, which were the legacy of the centrally planned economy, in order to reduce unemployment [52].

\section{Conclusions}

The multidimensional nature of rural areas means that they are extremely heterogeneous in their characteristics, especially across a large EU territorial area, indicating that all relevant features must be an integral part of both development strategies and rural policy 
making. When viewed according to other aspects, the division of NUTS 3 according to the EU classification into predominantly urban, intermediate, and predominantly rural areas using only population density does not in fact indicate a particular level of development. Classifications based on a single indicator do not adequately represent the EU's geographical area or rural areas. According to the EU classification, predominantly rural areas of Serbia cannot be compared to predominantly rural areas of Germany, Belgium, Netherland and other highly developed EU countries, especially in terms of socioeconomic performance. All districts in Serbia lagged economically, they were more similar to districts in the NMS, so the main hypothesis of this research was accepted. Comprehensive research is important for improving knowledge for the process of transforming Serbia's rural areas. Our empirical research was formulated in accordance with current methods confirmed in the international literature, which enabled a higher level of understanding of the heterogeneity of rural areas in Serbia and of the main trends present in these areas. The practical implication of this is reflected in the application of rural typology at the regional level through the Index of Socioeconomic Performance in the creation of measures of national policies and, specifically, rural development policy measures.

All strategies aimed at rural sustainable development must incorporate and utilize Serbia's as an EU candidate. Considering that the main goal of the EU's rural development policies is to preserve the vitality of rural areas as well as to improve the primary sector in Serbia, it would be strongly advisable for Serbia to apply the European model of agriculture, which is based on competitiveness, multifunctionality, and sustainability. In the sphere of agriculture, the core idea of multifunctionality highlights the various roles agriculture plays. In addition to food production, it involves high food quality by implementing good agricultural practices as well as preservation of the natural environment, which thus contributes to the economic and social development of both villages and of society as a whole.

The research indicated a regional development gap in most rural regions of Serbia in relation to more developed EU countries. This implies the need to abandon the centralized development model with the capital as the centre of decision making. Furthermore, this research can help other candidate countries, such as Montenegro, Albania, North Macedonia, and Turkey, determine their regions' position in relation to EU regions.

The originality of the research was reflected in the approach, which, when it comes to rural regions of Serbia, is not widely represented in the literature. The research of the rural area of Serbia was mostly sector-oriented, while the spatial approach was still in the background. Moreover, the most comprehensive research that analysed the rural areas of Serbia was conducted by Bogdanov et al. [57], but there was no study that dealt with the socioeconomic characteristics of rural regions of Serbia and their comparison with EU countries. Therefore, this paper filled the gap in the literature.

It is clear that the research into development processes in rural areas implies an integrated approach with the use of a much larger number of indicators. However, due to the available data in databases, this paper's main limitation was the usage of a scarce number of variables.

Future research will move towards identifying other factors contributing to the heterogeneity of rural regions, including demographic and spatial factors. This would mean responding appropriately to the demand for multidimensional access to rural areas in order to create a rural typology that would encompass Serbia and the EU at the regional level. Rural typology at the regional level could point to certain spatial patterns in the development of Serbia's rural areas relative to the EU countries.

Author Contributions: Conceptualization, Ž.J. and S.Z.; methodology and investigation, Ž.J., D.Đ. and S.Z.; writing — original draft preparation, review and editing, Ž.J., S.Z., D.Đ. and B.M.; visualization, Ž.J. and B.M.; supervision, S.Z. and D.Đ. All authors have read and agreed to the published version of the manuscript.

Funding: This research received no external funding.

Institutional Review Board Statement: Not applicable. 
Informed Consent Statement: Not applicable.

Acknowledgments: The paper presents a part of the research from the Erasmus + Jean Monnet project Agricultural Policy of European Union and its influence on competitiveness of agri-food products of Serbia-AgriCOM (620128-EPP-1-2020-1-RS-EPPJMO-MODULE).

Conflicts of Interest: The authors declare no conflict of interest.

\section{References}

1. European Commission. Modernising and Simplifying the CAP: Socio-Economic Challenges Facing EU Agriculture and Rural Areas. Brussels. 2017. Available online: https://ec.europa.eu/info/sites/info/files/food-farming-fisheries/key_policies/ documents/soc_background_final_en.pdf (accessed on 10 June 2021).

2. Organisation for Economic Co-Operation and Development. Rural 3.0. A Framework for Rural Development. Policy Note. 2018. Available online: https: / / www.oecd.org/cfe/regional-policy/Rural-3.0-Policy-Note.pdf (accessed on 15 July 2021).

3. López-Sanz, J.M.; Penelas-Leguía, A.; Gutiérrez-Rodríguez, P.; Cuesta-Valiño, P. Sustaina-ble Development and Rural Tourism in Depopulated Areas. Land 2021, 10, 985. [CrossRef]

4. Berc, G.; Kokorić, B.S.; Opačić, A. Dostupnost socijalnih prava i usluga za obitelji u općinama u ruralnim područjima Hrvatske. Rev. Za Soc. Polit. 2020, 27, 113-135. [CrossRef]

5. Böwer, U.; Turrini, A. EU accession: A road to fast-track convergence? Comp. Econ. Stud. 2010, 52, 181-205. [CrossRef]

6. Zekić, S.; Kleut, Ž.; Matkovski, B. An analysis of key indicators of rural development in Serbia: A comparison with EU countries. Econ. Ann. 2017, 62, 107-120. [CrossRef]

7. Matkovski, B.; Zekić, S.; Jurjević, Ž.; Đokić, D. The agribusiness sector as a regional export opportunity: Evidence for the Vojvodina region. Int. J. Emerg. Mark. 2021. [CrossRef]

8. Petrović, M.D.; Vujko, A.; Gajić, T.; Vuković, D.B.; Radovanović, M.; Jovanović, J.M.; Vuković, N. Tourism as an approach to sustainable rural development in post-socialist countries: A comparative study of Serbia and Slovenia. Sustainability 2018, 10, 54. [CrossRef]

9. Erjavec, E.; Volk, T.; Rednak, M.; Ciaian, P.; Lazdinis, M. Agricultural policies and European Union accession processes in the Western Balkans: Aspirations versus reality. Eurasian Geogr. Econ. 2021, 62, 46-75. [CrossRef]

10. Kurowska, K.; Kryszk, H.; Marks-Bielska, R.; Mika, M.; Leń, P. Conversion of agricultural and forest land to other purposes in the context of land protection: Evidence from Polish experience. Land Use Policy 2020, 95, 104614. [CrossRef]

11. Kurowska, K.; Marks-Bielska, R.; Bielski, S.; Aleknavičius, A.; Kowalczyk, C. Geographic Information Systems and the Sustainable Development of Rural Areas. Land 2021, 10, 6. [CrossRef]

12. Gabrić-Molnar, I.; Kovács, T. Support to the economic development of Vojvodina from Hungary. Anal. Ekon. Fak. u Subotici (The Annals of the Faculty of Economics in Subotica) 2019, 55, 3-15. [CrossRef]

13. European Commission. Serbia 2019 Report. 2019 Communication on EU Enlargement Policy; European Commission: Brussels, Belgium, 2019.

14. Zekić, S.; Matkovski, B.; Kleut, Ž. IPARD funds in the function of the development of the rural areas of the Republic of Serbia. Ekon. Horiz. 2016, 18, 169-180. [CrossRef]

15. Jurjević, Ž.; Bogićević, I.; Đokić, D.; Matkovski, B. Information technology as a factor of sustainable development of Serbian agriculture. Strateg. Manag. 2019, 24, 41-46. [CrossRef]

16. European Commission. Methodological Manual on Territorial Typologies; Publications Office of the European Union: Luxembourg, 2018; ISBN 978-92-79-94874-9; ISSN 2315-0815. [CrossRef]

17. Golić, R.; Joksimović, M. Regionalization of Serbia as an instrument of balanced regional development and reduction of regional inequalities. Zb. Rad.-Geogr. Fak. Univ. U Beogr. 2017, 65-1a, 209-226. [CrossRef]

18. Darvas, Z.; Mazza, J.; Midoes, C. How to Improve European Union Cohesion Policy for the Next Decade; No. 2019/8; Bruegel Policy Contribution: Brussels, Belgium, 2019.

19. Pagliacci, F.; Pavone, P.; Russo, M.; Giorgi, A. Regional structural heterogeneity: Evidence and policy implications for RIS3 in macro-regional strategies. Reg. Stud. 2019, 54, 765-775. [CrossRef]

20. European Commission. Eurostat Regional Yearbook; Publications Office of the European Union: Luxembourg, 2019.

21. European Commission, EAFRD Financial Instruments in 2014-2020 Rural Development Programmes-Final Report; European Commission: Brussels, Belgium, 2018.

22. Matthews, A. The EU's Common Agricultural Policy Post 2020: Directions of Change and Potential Trade and Market Effects; International Centre for Trade and Sustainable Development (ICTSD): Geneva, Switzerland, 2018; ISSN 1817-356X.

23. Vukadinović, S.; Ješić, J. Green jobs: Potential for employment in the Republic of Serbia. Anal. Ekon. Fak. u Subotici (The Annals of the Faculty of Economics in Subotica) 2019, 55, 115-129. [CrossRef]

24. Mitrović, J.; Mitrović, V. The development of social entrepreneurship and the perspective of its further affirmation in the overall development of Serbia. Anal. Ekon. Fak. u Subotici (The Annals of the Faculty of Economics in Subotica) 2019, 55, 81-97. [CrossRef]

25. Vincze, M.; Mezei, E. The increase of rural development measures efficiency at the micro-regions level by cluster analysis. A Romanian case study. East. J. Eur. Stud. 2011, 2, 13-39. 
26. Michalek, J.; Zarnekow, N. Application of the rural development index to analysis of rural regions in Poland and Slovakia. Soc. Indic. Res. 2012, 105, 1-37. [CrossRef]

27. Prus, P.; Dziekanski, P.; Bogusz, M.; Szczepanek, M. Spatial Differentiation of Agricultural Potential and the Level of Development of Voivodeships in Poland in 008-2018. Agriculture 2021, 11, 229. [CrossRef]

28. Domazet, I.; Zubović, J.; Lazić, M. Driving Factors of Serbian Competitiveness-Digital Economy and ICT. Strateg. Manag. 2018, 23, 20-28. [CrossRef]

29. Annoni, P.; Dijkstra, L.; Gargano, N. EU Regional Competitiveness Index (RCI 2016); Publications Office European Commission: Brussels, Belgium, 2017.

30. Gorzelak, G. Regional Policies in East-Central Europe. In Handbook of Regional Science; Fischer, M., Nijkamp, P., Eds.; Springer: Berlin, Germany, 2020. [CrossRef]

31. Bachtler, J.; Ferry, M. Cohesion policy in central and Eastern Europe. Is it fit for purpose? In Social and Economic Development in Central and Eastern Europe: Stability and Change after 1990; Gorzelak, G., Ed.; Routledge: New York, NY, USA; London, UK, 2020.

32. Sánchez-Zamora, P.; Gallardo-Cobos, R.; Ceña-Delgado, F. Rural areas face the economic crisis: Analyzing the determinants of successful territorial dynamics. J. Rural. Stud. 2014, 35, 11-25. [CrossRef]

33. Dyba, W.; Loewen, B.; Looga, J.; Zdražil, P. Regional development in Central-Eastern European countries at the beginning of the 21st century: Path dependence and effects of EU Cohesion Policy. Quaest. Geogr. 2018, 37, 77-92. [CrossRef]

34. Volk, T.; Rednak, M.; Erjavec, E.; Zhllima, E.; Gjeci, G.; Bajramovic, S.; Gjokaj, E. Monitoring of Agricultural Policy Developments in the Western Balkan Countries; No. JRC105784; Joint Research Centre (Sevillesite): Ispra, Italy, 2017. [CrossRef]

35. Papić, R.; Bogdanov, N. Rural Development Policy-A perspective of local actors in Serbia. Econ. Agric. 2015, 62, 1079-1093. [CrossRef]

36. European Commission. LEADER Local Development Strategies (LDS) Guidance on Design and Implementation; Publications Office of the European Union: Luxembourg, 2016. Available online: https://enrd.ec.europa.eu/sites/enrd/files/enrd-guidance_lds.pdf (accessed on 10 June 2021).

37. Balog, K. The concept and competitiveness of agile organization in the fourth industrial revolution's drift. Strateg. Manag. 2020, 25, 14-27. [CrossRef]

38. Martinović, M.; Ratkaj, I. Sustainable rural development in Serbia: Towards a quantitative typology of rural areas. Carpathian J. Earth Environ. Sci. 2015, 10, 37-48.

39. Harrington, V.; O'Donoghue, D. Rurality in England and Wales 1991: A replication and extension of the 1981 rurality index. Sociol. Rural. 1998, 38, 178-203. [CrossRef]

40. Hair, J.; Black, W.; Babin, B.; Anderson, R. Multivariate Data Analysis-A Global Perspective; Pearson: London, UK, 2014; ISBN 10: 1-292-02190-X, ISBN 13: 978-1-292-02190-4.

41. Osborne, J.W. What is rotating in exploratory factor analysis? Pract. Assess. Res. Eval. 2015, $20,2$.

42. Cloke, P.; Edwards, G. Rurality in England and Wales 1981: A replication of the 1971 index. Reg. Stud. 1986, 20, 289-306. [CrossRef]

43. Hedlund, M. Mapping the socioeconomic landscape of rural Sweden: Towards a typolgy of rural areas. Reg. Stud. 2016, 50, 460-474. [CrossRef]

44. Camaioni, B.; Esposti, R.; Lobianco, A.; Pagliacci, F.; Sotte, F. How rural is the EU RDP? An analysis through spatial fund allocation. Bio-Based Appl. Econ. 2013, 2, 277-300. [CrossRef]

45. Pinto-Correia, T.; Guiomar, N.; Guerra, C.A.; Carvalho-Ribeiro, S. Assessing the ability of rural areas to fulfil multiple societal demands. Land Use Policy 2016, 53, 86-96. [CrossRef]

46. Pagliacci, F. Regional paths towards Europe 2020 targets: A spatial approach. Eur. Plan. Stud. 2017, 25, 601-619. [CrossRef]

47. Tercet (2017) Regulation (EU) 2017/2391 of the European Parliament and of the Council of 12 December 2017 Amending Regulation (EC) No 1059/2003 as Regards the Territorial Typologies, Official Journal of the European Union. Available online: https:/ / eur-lex.europa.eu/legal-content/EN/TXT/?uri=celex:32017R2391 (accessed on 5 June 2021).

48. Copus, A.; Noguera, J. A typology of intermediate and predominantly rural NUTS 3 regions. EDORA Scientific Working Paper No. 24. EDORA Final Report, Annex 1 (Part C: Scientific Working Papers); ESPON: Luxembourg, 2013.

49. Eurostat, Employment (Thousand Persons) by NUTS 3 Regions. Available online: https://appsso.eurostat.ec.europa.eu/nui/ show.do?dataset=nama_10r_3empers\&lang=en\%20[Database:\%20Nama_10r_3empers]. (accessed on 5 December 2019).

50. Eurostat, Gross Domestic Product (GDP) at Current Market Prices by NUTS 3 Regions. Available online: https://appsso. eurostat.ec.europa.eu/nui/show.do?dataset=nama_10r_3gdp\&lang=en\%20[Database:\%20Nama_10r_3gdp]. (accessed on 5 December 2019).

51. Eurostat, Gross Value Added at Basic Prices by NUTS 3 Regions. Available online: http:/ / appsso.eurostat.ec.europa.eu/nui/ show.do?dataset=nama_10r_3gva\%20[Database:\%20Nama_10r_3gva]. (accessed on 5 December 2019).

52. The European Network for Rural Development, Employment and Social Inclusion. 2010. Available online: https://enrd.ec. europa.eu/sites / enrd / files /09AED062-D99D-0744-062C2B6F6E4785FB.pdf (accessed on 15 June 2021).

53. Spellerberg, A.; Huschka, D.; Habich, R. Quality of life in rural areas: Processes of divergence and convergence. Soc. Indic. Res. 2007, 83, 283-307. [CrossRef]

54. Biczkowski, M.; Jezierska-Thöle, A.; Rudnicki, R. The Impact of RDP Measures on the Diversification of Agriculture and Rural Development-Seeking Additional Livelihoods: The Case of Poland. Agriculture 2021, 11, 253. [CrossRef] 
55. Adamowicz, M. The Potential for Innovative and Smart Rural Development in the Peripheral Regions of Eastern Poland. Agriculture 2021, 11, 188. [CrossRef]

56. Karo, E.; Kattel, R. Economic development and evolving state capacities in Central and Eastern Europe: Can "smart specialization" make a difference? J. Econ. Policy Reform 2015, 18, 172-187. [CrossRef]

57. Bogdanov, N.; Meredith, D.; Efstratoglou, S. A typology of rural areas in Serbia. Ekon. Anal. 2008, 53, 7-29. [CrossRef] 